\title{
Generative and Predict-Observe-Explain Instructional Strategies: Towards Enhancing Basic Science Practical Skills of Lower Primary School Pupils
}

\author{
Famakinwa Adebayo, Bello Theodora Olufunke \\ Institute of Education, Obafemi Awolowo University, Ile-Ife, Osun State, Nigeria
}

Email address:

bledora@yahoo.co.uk (B. T. Olufunke)

\section{To cite this article:}

Famakinwa Adebayo, Bello Theodora Olufunke. Generative and Predict-Observe-Explain Instructional Strategies: Towards Enhancing Basic Science Practical Skills of Lower Primary School Pupils. International Journal of Elementary Education. Vol. 4, No. 4, 2015 , pp. 86-92. doi: 10.11648/j.ijeedu.20150404.12

\begin{abstract}
The study aimed at investigating the effectiveness of generative instructional strategy (GIS) and Predict-ObserveExplain (POE) in enhancing Basic Science practical skills of lower primary school pupils. It also compared the effects of the strategies on the Basic Science Practical Skills of the pupils. These were with a view to determining the effectiveness of the strategies in improving the practical skills of the lower primary school pupils in Basic Science. The study adopted the pre-test, post-test, control group, quasi-experimental research design. Three primary schools were selected from Ondo State in Nigeria using simple random sampling technique. Primary III pupils from three intact classes with class size between 25 - 35 pupils were purposively selected for the study. The instrument used for data collection was "Pupils' Basic Science Practical Skills Test" (PBSPST) which was designed to test learners' knowledge of Basic Science practical skills. Data collected were analyzed using Analysis of Covariance (ANCOVA). The result showed that there was no significant effect of GIS on primary school pupils' Basic Science practical skills while there was a significant effect of POE instructional strategy on pupils' Basic Science practical skills. Furthermore, result showed that there was a significant difference in the effects of generative and POE instructional strategies on pupils' Basic Science practical skills in favour of the POE instructional strategy compared with that of the GIS. The study concluded that the POE instructional strategy is a more effective means of improving Basic Science practical skills of lower primary school pupils and therefore recommends that primary school teachers should employ the use of this method in enhancing teaching and learning of Basic Science process skills.
\end{abstract}

Keywords: Predict-Observe-Explain, Generative, Basic Science, Practical Skills, Instructional Strategy

\section{Introduction}

The economic growth of any nation is hinged on the scientific and technological advancement of such nation. The main disparity among developed, developing and underdeveloped nations mainly hinged on the level of scientific and technological development of the nations and their ability to transform these developments into economical growth and sociological sustainability. In order to achieve this, scientific attitude must be cultivated in the minds of learners from early stage of their lives. This view has been confirmed in research that rapid learning occurs at the formative years more than at any other time of development (Nwagbara 2003, Isbell 2007). Ajayi (2009) therefore posited that the period needs to be harnessed for human capacity building by ascertaining effective learning in the learners' right from this stage of development; though the development of practical skills in the learners might appear as an uphill task when the peculiar characteristics of the learners in this age bracket are considered. They are very inquisitive, curious, and restless and they use all their senses to acquire meaning from their environment. Therefore, early childhood period is a crucial period in the life of the growing child that should be tapped and well directed to determine what type of adult the child would become (Maduewesi, 1999) in this technological and scientific age.

According to Bello (2012), science had been of great importance internationally for sustainable and socio-economic development as well as for technological advancement of nations. Bello (2012) further posited that the knowledge of science and technology is therefore a requirement in all countries and needed by all people globally due to numerous challenges that are facing them. Danjuma (2009) therefore 
opined that the teaching and learning of science is focused at developing the whole child in scientific skills, spirit of inquiry and other essential life-skills which will enable him/her function effectively. The view was in line with one of the objectives of early childhood education as stated in the National Policy on Education (2004).

Therefore, the role of Basic Science in the education of scientists, chemists and practitioners of other biological sciences are enormous which must begin at the early stage of development. Iroegbu (2009) stated that teaching this level of learners requires thoughtfulness as well as careful and skillful planning. Hence, children need to be helped to anticipate and cope with such changes, so that they can become useful, relevant and scientifically advanced in the modern society.

One of the important factors in the actualization of scientific advancement is the use of instructional strategies. Hence, the role of teacher in coping with science practical skills is to assist the pupils by equipping them with practical skills which are activity-oriented skills, as well as cognitive and psychomotor skills. These skills are acquired through instruction, direct experience and interaction with materials during practical teaching of science in laboratory (Njoku, 1999, Oginni, 2009 and Babajide 2010). Furthermore, Babajide (2010) emphasized that these skills are retained after the cognitive knowledge of science has been forgotten. To do this effectively, it requires not only the use and effort of good teachers but the use of activities-based instructional strategies; therefore, careful thought must be given to designing instructional strategies to help the learners master the objectives.

Apparently, there is a pragmatic need to explore how to assist the young learners to acquire science process skills especially the basic ones for total transformation in science subjects to be realistic. One of the ways of improving their science process skills is through the use of activity-oriented form of instructional strategies. The basic science subject is the foundation of scientific knowledge as it has contributed immensely to the existence and activities of man towards improved standard of living and growth in scientific discoveries. Despite the importance of science, there are a number of observable problems plaguing the teaching and learning of the subject, especially at the lower primary school level. Major among these problems is poor method of instruction (Kalijah, 2002). These may be the reasons for students' poor academic performance in the subject both at the secondary and tertiary school levels. Based on this deplorable trend of poor performance, basic science educators have designed some instructional strategies over the years to curb the problem of underachievement in the subject. For instance, Iroegbu (1998) designed Problem-Based learning for better achievement, problem solving and line graphing skills in Science.

There has been growing concern about low achievement of secondary school students in science based subjects. This was attributed to poor background in basic science at the primary school level (Aregbesola, 2003). This puts to question the reality and reliability of the high level of performance and by extension the quality and effectiveness of the teaching-learning process in schools. This trend of poor performance is not good enough for a scientific and technologically aspiring country like Nigeria where few numbers of persons are aspiring to study in the fields of science, technology and related disciplines.

Basic science prepares pupils to have solid foundation in science and builds them as future scientists. Poor performance of pupils in basic science has been a major concern for basic science educators and one of the major factors identified was lack of proper exposure to practical activities which has resulted in pupils' not developing appropriate practical skills needed for scientific and technological development (Ogini, 2009). This may also be linked to the use of instructional strategies which have not totally incorporated learners' previous knowledge and how they reasoned (Ezeliora, 2004; Okoronka, 2004; Okoli, 2006; Longjohn, 2009). This is more so as instructional strategies adopted teachers have not solved the problem probably because those strategies have not actually focused on learners as constructors of their own theories and knowledge.

Learners need to be made to construct their own knowledge and ideas in learning because they are the architects of their own learning and constructors of their own ideas and knowledge (Ausubel, 1968; Okoronka, 2004). Otherwise, continued use of teacher-centered or teacher-dominated strategies would yield nothing but learning by rote thereby making it difficult for students to recall pieces of information from memories. There is thus the need to explore how to assist the young learners to acquire science skills, especially in the practical. The Generative Instructional Strategy (GIS) and Predict-Observe-Explain Instructional Strategy (POEIS) have been used to improve the science practical skills of senior secondary school students in Physics (Babajide, 2010). The extent to which these strategies could influence same in the lower primary school pupils deserves empirical investigation; hence. It is against this background that this study was designed to compare the effects of GIS and POEIS on the basic science practical skills of lower primary school pupils.

\subsection{Generative Instructional Strategy (GIS)}

This is an instructional strategy that is practical activity instruction based on philosophy of discovery, where learners formulate their ideas, fact and theories through their direct interaction and manipulation of objects, materials and apparatus in practical activities classroom (Wittrock, 1991). The major idea of GIS is that learners not only make connection between the content being taught and their prior knowledge but also re-organize them for meaningful explanation. It is a functional model of instruction that focuses on the cognitive processes that learners use to comprehend concepts as well as the teaching and instructional procedures useful for increasing comprehension (Wittrock, 1992). This model states that the process of understanding new concepts involves active learners' generation of two types of meaningful relation. The first type is generating meaningful relation between information to be learned and learners' prior 
knowledge and experiences. The second type is generating meaningful relation among the parts of the information to be learned. It involves the process whereby teacher provides ample opportunities for learners to generate their own summaries, explanations and analogies from the materials presented in the class. Furthermore, it involves a process of conceptual change, motivation, attention and meta-cognition which is an essential part of science education. Bello, (2011) opined that using small group cooperative teaching method facilitates students' learning in Physics.

\subsection{Predict-Observe-Explain (POE) Instructional Strategy}

This is an instructional strategy based on the philosophy of practical activities which involves learning by doing (Zuziwe, 2006). Here learners perform three different tasks; predict, observe and explain. The POE was developed by White and Gunstone (1981) to uncover individual students' predictions, and their reasons for making these, about a specific event. It works best with demonstrations that allow immediate observations. White and Gunstone promoted the POE procedure as an efficient strategy for eliciting students' ideas and also promoting student discussion about their ideas. The POE procedure is based on the classic model of research where a hypothesis is stated and reasons are given for why this may be true, relevant data are gathered and results are discussed. It involves students predicting the result of a demonstration and discussing the reasons for their predictions; observing the demonstration and finally explaining any discrepancies between their predictions and observations.

\subsection{Objectives of the Study}

Basic science prepares pupils to have solid foundation in science and builds them as future scientists but poor performance of pupils in the subject has been a major concern for basic science educators. One of the major factors identified for this is lack of proper exposure to practical activities which may be responsible for pupils' not developing appropriate practical skills needed for scientific and technological development (Ogini, 2009). It is therefore pertinent to explore how to assist the young learners to acquire science skills, especially in practice. Therefore, the specific objectives of the study are to:

(i) Determine the effect of generative instructional strategy on pupils' basic science practical skills;

(ii) Determine the effect of predict-observe-explain instructional strategy on pupils' basic science practical skills; and

(iii) Compare the effect of generative and predict-observeexplain instructional strategies on the basic science practical skills of pupils;

\subsection{Research Hypotheses}

This is a statement of guess about the solution to the identified problem. It provides the necessary guide and direction for solving the problem under this study. Therefore, in order to establish the stated objectives, hypotheses were formulated and tested based on data collected and analyzed. The research hypotheses generated to guide the study are:

$\mathrm{H}_{01}$ There is no significant effect of generative instructional strategy on pupils' basic science practical skills

$\mathrm{H}_{\mathrm{o} 2}$ There is no significant effect of predict-observeexplain instructional strategy on pupils' basic science practical skills

$\mathrm{H}_{03}$ There is no significant difference in the effect between generative and predict-observe-explain instructional strategies on the basic science practical skills of pupils.

\section{Methodology}

\subsection{Research Design}

Research design provides the strategy by which the research was carried out, specifies the methods that were employed in the collection and analysis of data. The research design for this study was pre-test, post-test, control group, quasi-experimental design. The design is represented schematically as follows:

$\begin{array}{llll}\mathrm{O}_{1} & \mathrm{x}_{1} & \mathrm{O}_{4} & \text { - Control group } \\ \mathrm{O}_{2} & \mathrm{x}_{2} & 0_{5} & \text { - Experimental group 1 } \\ \mathrm{O}_{3} & \mathrm{x}_{3} & \mathrm{O}_{6} & \text { - Experimental group 2 }\end{array}$

$\mathrm{O}_{1}, \mathrm{O}_{2}$ and $\mathrm{O}_{3}$ are the pre-test scores of control, experimental 1 , and 2 groups respectively. Also, $\mathrm{O}_{4}, \mathrm{O}_{5}$ and $\mathrm{O}_{6}$ are the post-test scores of control, experimental 1 , and 2 groups respectively.

$$
\begin{aligned}
& \mathrm{X}_{1}=\text { Conventional Teaching Strategy (Control) } \\
& \mathrm{X}_{2}=\text { Predict-Observe-Explain Instructional Strategy } \\
& \mathrm{X}_{3}=\text { Generative Instructional Strategy }
\end{aligned}
$$

\subsection{Population, Sample and Sampling Technique}

The study population comprised all pupils in lower primary schools in Ondo West Local Government Area of Ondo State. The sample consisted of three public primary schools randomly selected from the chosen LGA. One arm out of primary three (3) classes consisting of thirty pupils of intact class in each school was purposively assigned to one of the instructional strategies, making a total of ninety pupils used for the study. The chosen schools were located in an urban area in the southwestern region of Nigeria. Majority of the people in this area are civil servants and traders while few percentages of them are farmers. There are private and public primary schools in this location but the sample used for this study were selected in the public schools. This is because most of the pupils attending public schools are low-earnings and low-class citizens who do not have access to basic facilities for effective classroom teaching/learning process.

\subsection{Instrumentation}

The instrument used for data collection is a self-designed instrument titled "Pupils' Basic Science Practical Skills Test" (PBSPST). This was designed to determine the efficacy of the practical skills' lesson of the pupils' basic science. It also tested pupils' abilities to make some deductions on the demonstrations performed based on the six basic science 
process skills of observing, measuring, classifying, predicting, inferring communicating skills. The instrument contained thirty-item multiple pictorials' choice test on primary three basic science modules. The items have 50 sub-items that carried two marks each and a total mark of 100 . The instrument was subjected to face and content validation by experts in basic science and early childhood education. The instructional guides were given to primary science experts and three primary three basic science teachers for validation. They went through them with respect to the adequacy, structure, language and relevance of the instrument. Thereafter, a pilot study was carried out using 25 primary three pupils who were selected outside the sample used for the study to ascertain the reliability of the instrument. The reliability coefficient (r) was calculated for PBSPST using test- retest method of spearman's rho $(\rho)$ which took place after two weeks of the first test and this was found to be 0.73 . This is an indication that the instrument was reliable and suitable for the study.

The whole process of data collection for the study from the pre-test to post-test took seven weeks. After the administration of pre-test, the application of treatments in the two experimental schools and one control school took six weeks of three periods per week to be completed. The procedural steps that were used to carry out the demonstrations were provided for each treatment. The post-test was administered to all the participating pupils after the completion of treatments. The PBSPST results for both pre-test and post-test were scored, collated and analyzed.

\subsection{The Instructional Package (IP)}

The instructional package was used to arouse the learners' performance in the six Basic Science practical skills (observing, measuring, inferring, classifying, predicting and communicating skills) that were demonstrated during the performance and reporting of the experiments/demonstrations in the practical class. The instructional package that was used for the study was divided into three parts, namely:

i. Instructional Guide on Conventional Teaching Strategy (IGCTS) for control group

ii. Instructional Guide on Predict-Observe-Explain Instructional Strategy (IGPOEIS) for experimental group one

iii. Instructional Guide on Generative Instructional Strategy (IGGIS) for experimental group two
All the instructional guides contained the procedures for the two experimental and control groups for the practical topics that were used for the study.

\subsection{Procedure for Data Collection}

To manage the research effectively, three primary schools were purposively selected. The process of data collection for the study took six weeks. It started with the approval for the use of the schools from the various head-mistresses. The schools' head-mistresses were intimated with the purpose of the study followed by the class-teachers of the selected classes. The researcher purposively assigned specific instructional strategy to each participating school while the corresponding arm of the class was purposively assigned to one control and two instructional strategies.

After administering the pre-test on all the 90 participants, the application of treatments in the two experimental schools and one control school took was carried out for six weeks. Three periods was given per week. The lesson guides containing the five topics were used by the researcher for five weeks of the treatments. Completions of the treatments were done with clear-cut instructional guides that directed the researcher's activities during the treatments.

Fifteen demonstrations were performed by the pupils which contained five topics derived from the Primary Three Module-based on (i) soil and sky (soil particles, droplets, weather and us), (ii) living things (flowers, plant parts, skin, growing seeds and leaves), (iii) materials and forces (floating and types of forces), (iv) ourselves/environment (care tools, washing hands and adult differences) and (v) measurement. The procedural steps that were used to carry out the demonstrations were provided for each treatment.

Finally the post-test was administered to all the participating pupils after the completion of treatments. The PBSPST results for both pre-test and post-test were scored, collated, coded and subjected to the Statistical Package for Social Sciences (SPSS) data analysis procedures. All the research Hypotheses were answered using Analysis of Covariance (ANCOVA).

\section{Results}

The data collected were analyzed and the results of the analyses are presented in the tables below:

Table 1. Summary of ANCOVA of Post-test Scores by treatment.

\begin{tabular}{|c|c|c|c|c|c|c|}
\hline \multirow{2}{*}{ Source of Variance } & & \multicolumn{5}{|c|}{ Hierarchical Method } \\
\hline & & Sum of Squares & df & Mean Square & $\mathbf{F}$ & Sig. \\
\hline \multirow{4}{*}{ Covariates } & Pre-test score & 8624.82 & 1 & 8624.82 & 58.009 & $0.00 *$ \\
\hline & (Combined) & 1882.04 & 3 & 627.35 & 4.219 & 0.01 \\
\hline & Model & 10738.80 & 6 & 1789.80 & 12.04 & 0.00 \\
\hline & Residual & 12340.49 & 83 & 148.68 & & \\
\hline Total & & 23079.89 & 89 & 2593.18 & & \\
\hline
\end{tabular}

*Significant at $\mathrm{p}<0.05$

a. Post test score by Treatment, with Pre-test score

b. Covariates entered first 
From table 1 the pre-test scores of pupils in the three groups were significantly different $(\mathrm{F}=58.01, \mathrm{p}<0.05)$. This means that the three groups were not comparable initially and justify the use of ANCOVA which adjusted the post-test scores based on the initial differences obtained.

\subsection{Research Hypothesis One $\left(\mathrm{H}_{01}\right)$}

There is no significant effect of generative instructional strategy on pupils' basic science practical skills.

To test this hypothesis, Analysis of Covariance (ANCOVA) was computed and the result is presented in table 2 .

Table 2. ANCOVA showing the effect of GIS.

\begin{tabular}{|c|c|c|c|c|c|c|}
\hline Source & Type III Sum of Squares & df & Mean Square & $\mathbf{F}$ & Sig. & Partial Eta Squared \\
\hline Corrected Model & $2635.16^{\mathrm{a}}$ & 2 & 1317.58 & 8.20 & .00 & .22 \\
\hline Intercept & 2094.28 & 1 & 2094.28 & 13.04 & .00 & .19 \\
\hline Pretest & 1012.76 & 1 & 1012.76 & 6.31 & .02 & .10 \\
\hline Treatment-generative & 180.82 & 1 & 180.82 & 1.13 & .29 & .02 \\
\hline Total & 19727.00 & 60 & & & & \\
\hline Corrected Total & 11790.40 & 59 & & & & \\
\hline
\end{tabular}

a. R Squared $=.224$ (Adjusted R Squared $=.196$ )

Table 2 shows the effect of GIS on pupils' practical skills in basic science. From the result, there is no significant effect of GIS on pupils' practical skills in basic science in the study area $(\mathrm{F}=1.13 ; \mathrm{p}>0.05)$. To this end, hypothesis one is sustained, therefore, there is no significant effect of GIS on pupils basic science practical skills.

\subsection{Research Hypothesis Two $\left(\mathrm{H}_{02}\right)$}

There is no significant effect of Predict-Observe-Explain instructional strategy on pupils' basic science practical skills.

To test this hypothesis, ANCOVA was computed and the results were presented in table 3 .

Table 3 shows the effect of POE instructional strategy on pupils' practical skills in basic science. From the result, there is significant effect of POE instructional strategy on pupils' practical skills in basic science in the study area $(\mathrm{F}=9.62$; $\mathrm{p}<0.05)$. There is difference in the mean scores of POE and conventional groups in favour of POE $(\overline{\mathrm{x}}=66.68)$ as shown in table 4b.Hence, hypothesis two is hereby rejected. Therefore, there is significant effect of Predict-ObserveExplain instructional strategy on pupils basic science practical skills.

Table 3. ANCOVA showing the effect of POEIS.

\begin{tabular}{llllll}
\hline Source & Type III Sum of Squares & df & Mean Square & F & Sig. \\
\hline Corrected Model & $10384.31^{\mathrm{a}}$ & 2 & 5192.15 & 48.21 & .00 \\
Intercept & 1468.39 & 1 & 1468.39 & 13.63 & .63 \\
Pretest & 5157.64 & 1 & 5157.64 & 47.89 & .00 \\
Treatment- POE & 1036.51 & 1 & 1036.51 & 9.62 & .00 \\
Total & 230608.00 & 60 & & & .00 \\
Corrected Total & 16523.73 & 59 & & & .14 \\
\hline
\end{tabular}

a. $\mathrm{R}$ Squared $=.628$ (Adjusted R Squared $=.615$ )

Table 4a. ANCOVA showing the comparative effects of GIS and POEIS.

\begin{tabular}{|c|c|c|c|c|c|c|}
\hline Source & Type III Sum of Squares & df & Mean Square & $\mathbf{F}$ & Sig. & Partial Eta Squared \\
\hline Corrected Model & $10466.92^{\mathrm{a}}$ & 3 & 3488.97 & 23.79 & .00 & .45 \\
\hline Intercept & 2188.86 & 1 & 2188.86 & 14.93 & .00 & .15 \\
\hline Pretest & 5217.50 & 1 & 5217.50 & 35.58 & .00 & .29 \\
\hline GIS & 12.62 & 1 & 12.62 & .09 & .77 & .00 \\
\hline “POE & 1339.94 & 1 & 1339.94 & 9.14 & .00 & .10 \\
\hline Total & 348040.00 & 90 & & & & \\
\hline
\end{tabular}

**Significant at 0.05 level.

Table 4b. Multiple classification analysis of post-test practical skills scores according to treatment.

\begin{tabular}{lllllll}
\hline & No & Unadjusted Mean & $\begin{array}{l}\text { Adjusted Mean for Factors and } \\
\text { Covariates }\end{array}$ & $\begin{array}{l}\text { Unadjusted Deviation } \\
\text { Factors and Covariates }\end{array}$ \\
\hline \multirow{3}{*}{ Treatment } & Conventional & 30 & 50.40 & 56.14 & -9.69 & -3.95 \\
& POE & 30 & 69.07 & 66.68 & 8.98 & -71 \\
$\mathrm{R}=.675$ & Generative & 30 & 60.80 & 57.45 & & -2.64 \\
$\mathrm{R}$ Square $=.455$ & & & & & \\
\hline
\end{tabular}




\subsection{Research Hypothesis Three $\left(\mathrm{H}_{03}\right)$}

There is no significant difference between the effect of generative and predict-observe-explain instructional strategies on the basic science practical skills of pupils.

To test this hypothesis, ANCOVA was computed and the results were presented in tables $4 a$ and $4 b$.

Table 4a compares the effect of GIS and POEIS on the basic science practical skills of pupils. From the result, there is a significant difference between the effect of POEIS and GIS on pupils' practical skills in basic science $(\overline{\mathrm{x}}=14.93$ : $\mathrm{p}<$ 0.05 ) and the difference favours the higher performance of the pupils in the POE group $(\overline{\mathrm{x}}=66.68)$ against that of the generative group $(\bar{x}=57.45)$ as shown in table $4 b$.This implies that there is significant difference between the effect of GIS and POEIS on the basic science practical skills of pupils. Therefore, hypothesis three is rejected.

\subsection{Discussion}

The study examined the effects of GIS and POEIS on basic science practical skills of pupils. The findings of hypothesis one showed that there is no significant effect in the development of practical skills by pupils using GIS. This finding is not in line with the findings of Emilly and Zee (2000) and Babajide (2010) who found that the GIS was effective in the development of practical skills in the senior secondary schools' students. This could be due to the fact that learners used in this research are too young to use GIS which requires taking full control in setting up of experiment/demonstration, as well as in the manipulation of the apparatus. Hence, GIS might not help in the development of practical skills among lower primary school basic science pupils.

Hypothesis two findings showed that there is significant effect in the development of practical skills by pupils using POEIS. This finding is in line with the findings of Babajide (2010) who found that the POEIS was effective in the development of practical skills in students of senior secondary schools Physics. Therefore, POEIS is effective in both lower primary schools as well as in senior secondary schools.

Hypothesis three findings indicated that there is significant difference in the effect between POEIS and GIS. The POE instructional strategy is better than GIS in the development of practical skills because the mean post-test practical skills scores in the POE group $(\overline{\mathrm{x}}=66.68)$ is higher than $(\overline{\mathrm{x}}=57.45)$ in the Generative group. Hence, the practical skills acquired by pupils in POE group were higher than those acquired by pupils in Generative group. The POEIS has been used for eliciting pupils' understanding and promoting conceptual change. Therefore, pupils in the POE group performed better than the other groups. This finding is in line with the finding of Babajide (2010), Ogunleye and Babajide (2011) who found that the POEIS was more effective than the GIS in the development of practical skills in Physics.

\subsection{Conclusion}

This study had revealed the efficacy of each of the two activity-based instructional strategies on pupils' practical skills development in basic science of lower primary school. The findings had specifically indicated that the use of POEIS is effective at improving lower primary school pupils' practical skills in basic science. This would assist basic science teachers in selecting appropriate methods of instruction at improving the development of practical skills of pupils in basic science in general as well as preparing the pupils for future profession in science.

\section{Recommendations}

Based on the findings of this study, the following recommendations are proposed to assist the teachers on the ways to use activity-oriented form of instruction in the basic science classroom, so that the pupils could acquire practical skills especially in the science for total transformation as this will also help the young learners to cultivate scientific culture and acquire such skills and competence that will make them future scientists.

- POEIS is strongly recommended for developing practical skills among lower primary school pupils.

- Pupils should constantly be exposed to practical aspects of basic science.

- Government, ministries and State Governments should organize workshops and seminars for basic science teachers on improvisation of basic science materials.

- Basic science teachers should be trained on the effective use of POEIS through workshops and seminars' exposure.

- Practical activities' lesson should be included in the lower primary school time-table.

\section{References}

[1] Ajayi, H. O. (2009). Classroom Environment: Another Teacher of the Pre-School Children. International Journal of Contemporary Issues in Education (Special Edition).

[2] Aregbesola, T. O. (2003). Dissemination of Science and Technological Knowledge in Nigeria Primary School Level. In Ehindero O. J. and Aladejana F. O. (Eds) Readings in Early Childhood Education, Literamed Publications Limited, Ghana, pp 234-246.

[3] Ausubel, D. P. (1968).Education Psychology A Cognitive View. New York: Grune and Stratton.

[4] Babajide, V. F. T. (2010). Fostering the Development of Practical Skills among Secondary School Physics Students: Implications for Science Teaching. International Journal of Contemporary Issues in Education. (Special Edition, Vol. 2.).

[5] Bello, T. O. (2011). Effect of group instructional strategy on students' performance in selected Physics concepts. The African Symposium: An on-line Journal of African Educational Research Network, 11(1), 71-79. 
[6] Bello, T. O. (2012). Effect of Availability and Utilization of Physics Laboratory Equipment on Students' Academic Achievement in Senior Secondary Schools Physics. World Journal of Education. Vol. 2 (5), 1-7.

[7] Danjuma, I. M. (2009).The Use of Concept Mapping and Activity Based Strategies for teaching of primary Science. A paper presented at workshop organized by Bauchi State $S U B E B$ in collaboration with Garu Consults Ltd. $26^{\text {th }}-28^{\text {th }}$ March, 2009.

[8] Emilly, H. and Zee, V. (2000). Analysis of Students' Generated Inquiry Discussion. International Journal of Science Education. Vol. 22 no. 2: 115-147.

[9] Ezeliora, B. (2004). Motivating Secondary School Science Teacher to face the Challenges of third Millennium. Journal of the Science Teacher Association of Nigeria. Vol, 39, no. $1 \& 2$.

[10] Federal Republic of Nigeria (2004). National Policy on Education. Lagos: NERDC Press.

[11] Iroegbu, T. O. (1998). Problem-based Learning, Numerical Ability and Gender as Determinants of Achievement in Line Graphing Skills in Senior Secondary Physics. An Unpublished Ph.D. Thesis University of Ibadan, Nigeria.

[12] Iroegbu, V. I. (2009).Enriching English Language Teaching and Learning in Early Childhood Classroom through Modeling Strategy. International Journal of Contemporary Issues in Education, vol. 2.

[13] Isbell, R (2007). An environment that positively impact young children. Early Childhood NEWS; the Professional Resources for Teachers and Parents Excellence Learning Corporation.

[14] Johnson, D. and Johnson, R. (1991).Learning Together and Alone Cooperation, Competition and Individualization. New Jersey, Prentice Hall inc. Endlewood Cliffs.

[15] Kalijah, M. S. (2002). Education, Training and Careers in Physics for Women in Malaysia. IUPAP International Conference on Women in Physics, UNESCO. Paris France.

[16] Longjohn, I. T. (2009). Effect of Game Method of Teaching in Students' Academic Achievement in Chemistry. Journal of the Science Teacher Association of Nigeria, Vol 44 (1 \&2).
[17] Maduewesi, E. J. (1999). Early Childhood Education; Theory and practice. Lagos: Macmillan Nigeria publishers.

[18] Njoku, Z. C. (1999). A scale for the assessment of students' chemistry practical skills in secondary schools. Journal of the Science Teacher Association of Nigeria, Vol 34, nos 1 \& 2, 83 - 89 .

[19] Nwagbara, C. (2003). Early Years Learning; Related Issues in Early Childhood Education. TAIT Publications, Ibadan.

[20] Oginni, A. M. (2009). Selected Students Aptitude Indices and School Factors as Predictors of Senior Secondary School Students Learning Outcomes in Chemistry in Lagos State. An Unpublished Ph.D. Thesis University of Ibadan.

[21] Ogunleye, B. O. and Babajide, V. F. (2011). Generative Instructional Strategy Enhances Senior Secondary Schools Students' Achievement in Physics. European Journal of Educational Studies, 3(3), 453 - 461.

[22] Okoli, J. N. (2006). Effects of Investigative Laboratory Approach and Exposition Retrieval of Acquisition of Science Process Skills by Biology Students of different levels of Scientific Literacy. Journal of Science Teachers Association of Nigeria, Vol. 41, nos. $1 \& 2$.

[23] Okoronka, A. U. (2004). Model Based Instructional Strategies as Determinants of Students' Learning Outcomes in Secondary Physics in Lagos State. An Unpublished Ph.D. Thesis, University of Ibadan, Nigeria.

[24] White, B. and Gunstone, R. F., Champagne, A. B., \&Klopfer, L.E. (1981). Instruction for Understanding: A Case Study. Australian Science Teachers' Journal, 27(3), 27-32.

[25] Wittrock, M. C. (1991). Generative Teaching of Comprehension. Elementary School Journal, Vol. 92, No. 2, 169-180.

[26] Wittrock, M. C. (1992). Generative Learning Process of the Brain. Educational Psychologist. pp 27.

[27] Zuziwe, M. (2006). Using the Predict-Observe-Explain Technique to Enhance the Students' Understanding of Chemical Reaction. (Short report on pilot study).University of Pittsburgh. Retrieved from: mthembuz@und.nuiza. 